Subscriber access provided by Caltech Library

\title{
Communication
}

\section{Lewis Acid Enhancement of Proton Induced CO Cleavage: Bond Weakening and Ligand Residence Time Effects} Joshua A. Buss, David G. VanderVelde, and Theodor Agapie

J. Am. Chem. Soc., Just Accepted Manuscript • DOI: 10.1021/jacs.8b05874 • Publication Date (Web): 23 Jul 2018

Downloaded from http://pubs.acs.org on July 23, 2018

\section{Just Accepted}

"Just Accepted" manuscripts have been peer-reviewed and accepted for publication. They are posted online prior to technical editing, formatting for publication and author proofing. The American Chemical Society provides "Just Accepted" as a service to the research community to expedite the dissemination of scientific material as soon as possible after acceptance. "Just Accepted" manuscripts appear in full in PDF format accompanied by an HTML abstract. "Just Accepted" manuscripts have been fully peer reviewed, but should not be considered the official version of record. They are citable by the Digital Object Identifier (DOI®). "Just Accepted" is an optional service offered to authors. Therefore, the "Just Accepted" Web site may not include all articles that will be published in the journal. After a manuscript is technically edited and formatted, it will be removed from the "Just Accepted" Web site and published as an ASAP article. Note that technical editing may introduce minor changes to the manuscript text and/or graphics which could affect content, and all legal disclaimers and ethical guidelines that apply to the journal pertain. ACS cannot be held responsible for errors or consequences arising from the use of information contained in these "Just Accepted" manuscripts. 
As the terminal product of fossil fuel combustion, the conversion of carbon dioxide $\left(\mathrm{CO}_{2}\right)$ to energy-dense, liquid fuels is a necessary step in closing an anthropogenic carbon cycle. ${ }^{1}$ Technologies for the capture, ${ }^{2}$ copolymerization, ${ }^{3}$ and hydrogenation ${ }^{4}$ of $\mathrm{CO}_{2}$ have recently emerged, and their study and design is topical. However, the controlled reduction of $\mathrm{CO}_{2}$ with protons and electrons is most relevant to artificial photosynthesis and couples most directly to the storage of renewable energy in chemical bonds. ${ }^{1,5}$ Due to the kinetic stability of $\mathrm{CO}_{2},{ }^{6}$ the range of products formed in a narrow potential window, and competing reduc$\begin{array}{llllllllllllllllll}\mathrm{t} & \mathrm{i} & \mathrm{o} & \mathrm{n} & \mathrm{r} & \mathrm{e} & \mathrm{a} & \mathrm{c} & \mathrm{t} & \mathrm{i} & \mathrm{o} & \mathrm{n} & \mathrm{s} & , & 5 & \mathrm{~b} & & \end{array}$

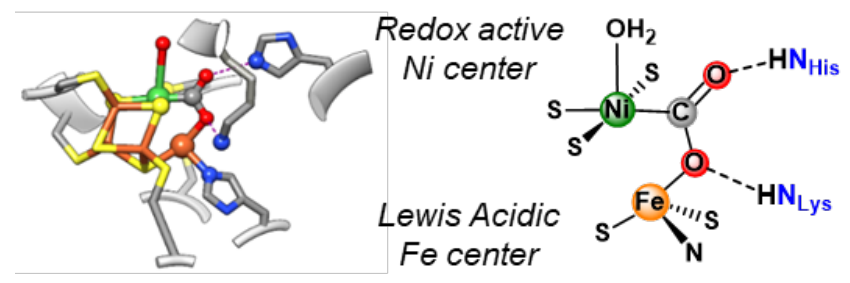

Figure 1. Solid-state structure (left, PDB: $4 \mathrm{UDX})^{7}$ and schematic representation (right) of the $\mathrm{CO}_{2}$-bound $\mathrm{NiFe}-\mathrm{CODH}$ active site. efficient and robust catalysts capable of the selective reduction of $\mathrm{CO}_{2}$ remain a subject of significant interest. ${ }^{6 a}$

In nature, the two-electron two-proton reduction of $\mathrm{CO}_{2}$ is executed reversibly by CO-Dehydrogenases $(\mathrm{CODH}) .{ }^{9}$ The enzyme active site of $\mathrm{NiFe} \mathrm{CODH}$ features a redox active $\mathrm{Ni}$ center and an $\mathrm{Fe}(\mathrm{III})$ ion that coordinate $\mathrm{CO}_{2}$ in a $\mu-\eta \mathrm{C}: \eta \mathrm{O}$ binding motif (Figure 1$) .{ }^{\mathrm{g}}$ Added Lewis acids (LAs) promote rate enhancements and redox potential shifts in electrocatalytic $\mathrm{CO}_{2}$ reduction. ${ }^{10}$ This strategy of cooperative $\mathrm{CO}_{2}$ activation has inspired molecular mimics in the form of ligand scaffolds that feature LAs in the coordination sphere, ${ }^{11}$ heterobimetallic complexes, ${ }^{12}$ exogenous $\mathrm{LA}$ addition to $\mathrm{CO}_{2}$ bound metal complexes or $\mathrm{CO}_{2}$ reduction intermediates, ${ }^{9 a, 13}$ and reduction catalysis combining transition metals and diboranes. ${ }^{14}$ Though LAs are capable of promoting $\mathrm{CO}_{2}$ binding ${ }^{9 \mathrm{a}}$ and increasing the degree of $\mathrm{CO}_{2}$ activation, ${ }^{13 \mathrm{c}}$ systematic investigations of their effect on reactivity of the bound $\mathrm{CO}_{2}$ unit remain scant. Herein, we describe a study correlating Lewis acidity and the degree of $\mathrm{CO}_{2}$ activation in a low-valent Mo complex. ${ }^{15}$ Moreover, we demonstrate that $\mathrm{LA}$ addition facilitates $\mathrm{C}-\mathrm{O}$ bond cleavage, chemistry that does not proceed from the parent LA-free $\mathrm{CO}_{2}$ complex, via both kinetic stabilization and increased small molecule activation.

Dinitrogen adduct 1 reversibly binds $\mathrm{CO}_{2}$, resulting in formation of an $\eta^{2}-\mathrm{CO}_{2}$ complex, 2 (Scheme 1 ). Under an atmosphere of ${ }^{13} \mathrm{CO}_{2}$, the ${ }^{31} \mathrm{P}\left\{{ }^{1} \mathrm{H}\right\}$ and ${ }^{13} \mathrm{C}\left\{{ }^{1} \mathrm{H}\right\}$ NMR spectra display a coupling doublet and triplet at 62.8 and $192.4 \mathrm{ppm}\left({ }^{2} J(\mathrm{C}, \mathrm{P})=29.3 \mathrm{~Hz}\right)$, respectively, consistent with coordination of a single ${ }^{13} \mathrm{CO}_{2}$ molecule. ${ }^{16}$ The IR spectrum of 2 displays stretches at 1716 and $1198 \mathrm{~cm}^{-1}$, sensitive to ${ }^{12} \mathrm{C} /{ }^{13} \mathrm{C}$ isotopic labeling, again supporting a bound $\mathrm{CO}_{2}$ motif. ${ }^{16-17}$ Solid-state analysis of single crystals of 2 grown under a $\mathrm{CO}_{2}$ atmosphere confirm the $\eta^{2}$ binding mode (Figure 2).

Interested in the thermodynamics of this reversible small molecule binding, longitudinal relaxation $\left(T_{1}\right)$ times were measured for the relevant ${ }^{13} \mathrm{C}$ and ${ }^{15} \mathrm{~N}$ resonances of an equilibrium mixture of $1-{ }^{15} \mathrm{~N}, 2-{ }^{13} \mathrm{C}$, ${ }^{15} \mathrm{~N}_{2}$ and ${ }^{13} \mathrm{CO}_{2}$. Uncharacteristically short values 

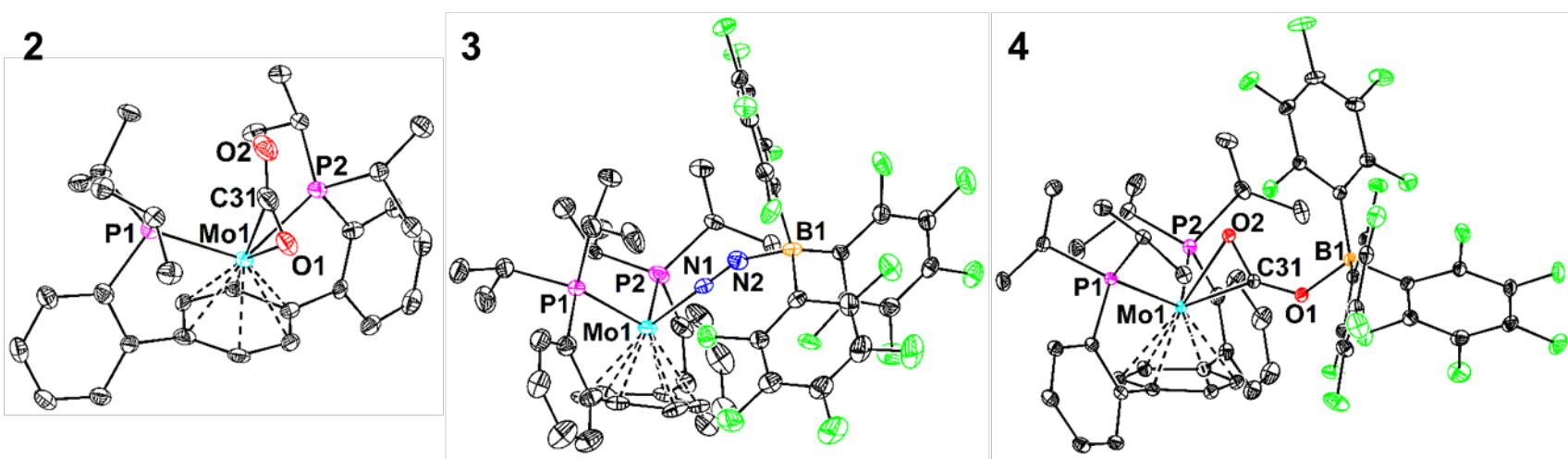

Figure 2. Solid-state structures of complexes 2-4. Thermal anisotropic displacement ellipsoids are shown at the $50 \%$ probability level. $\mathrm{H}$-atoms are omitted for clarity. Selected bond distances $[\AA]$ and angles $\left[^{\circ}\right]$ - 3: Mo1-N1 1.913(2), N1-N2 1.163(3), N2-B1 1.585(37), LMo1-N1-N2 179.1(3), $\angle \mathrm{N} 1-\mathrm{N} 2-\mathrm{B} 1$ 158.2(1.2); 4: Mo1-O2 2.2535(6), Mo1-C31 2.0574(8), O2-C31 1.246(1), C31-O1 1.275(1), O1-B1 1.554(1), $\angle \mathrm{O} 2-\mathrm{C} 31-\mathrm{O} 1$ 130.93(8), ८C31-O1-B1 132.13(7).

Scheme 1. $\mathrm{CO}_{2}$ binding and LA adduct formation at low-valent Mo.
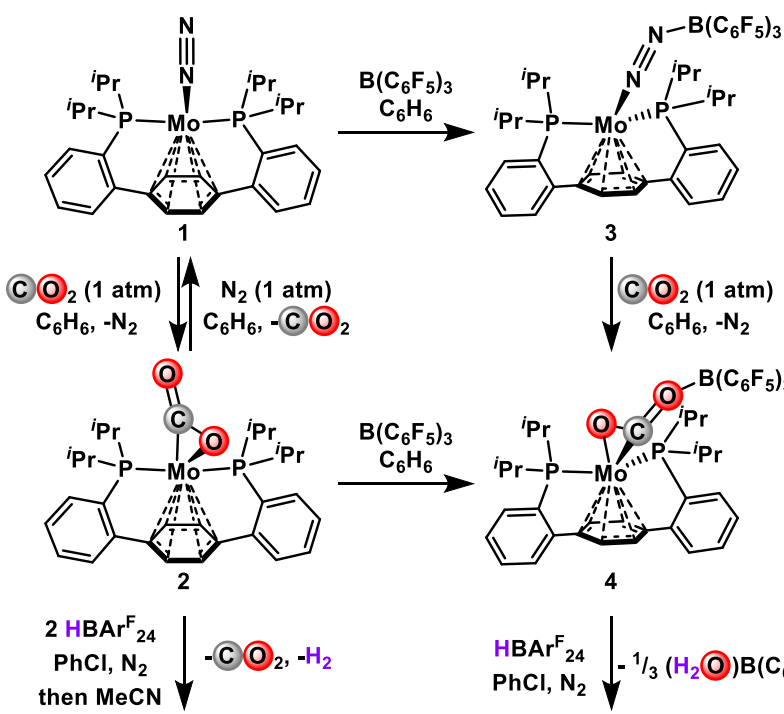
then $\mathrm{MeCN}$
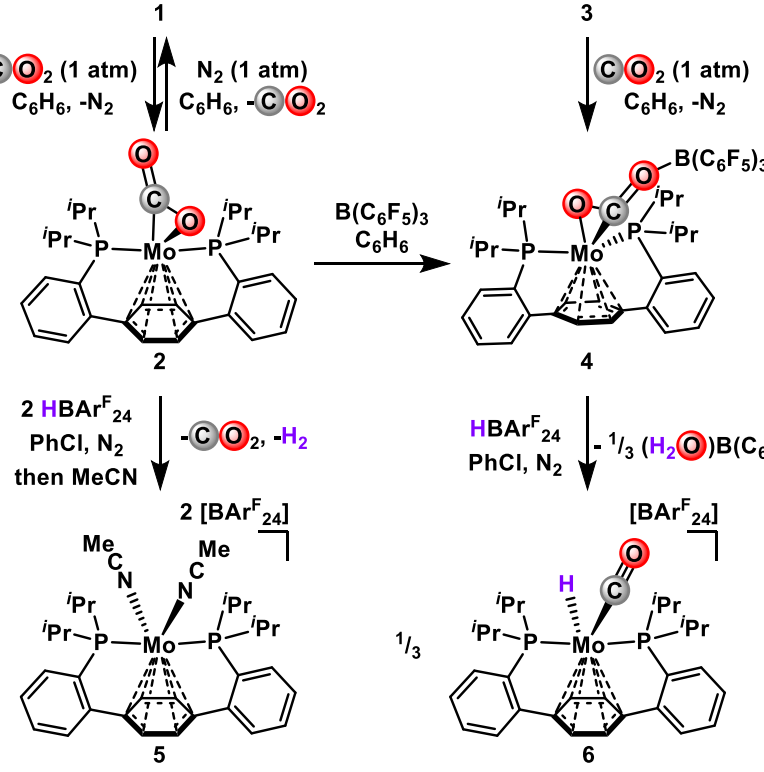

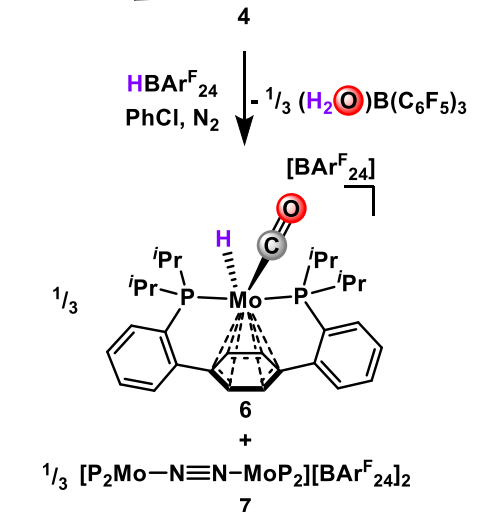

${ }^{\mathrm{t}} \mathrm{HBAr}^{\mathrm{F}}{ }_{24}=\left[\mathrm{H}\left(\mathrm{Et}_{2} \mathrm{O}\right)_{2}\right]\left[\mathrm{BAr}^{\mathrm{F}}{ }_{24}\right]\left(\mathrm{BAr}{ }^{\mathrm{F}}{ }_{24}=\right.$ tetrakis$[3,5$-bis $($ trifluoromethyl $)$ phenyl]borate)

were observed for $1{ }^{15} \mathrm{~N}$, free ${ }^{15} \mathrm{~N}_{2}, 2-{ }^{13} \mathrm{C}$, and free ${ }^{13} \mathrm{CO}_{2}-5.1(4)$, 4.9(3), 12.5(4), and 16.8(7) s, respectively. ${ }^{18}$ These short and near equivalent $T_{1}$ times suggest an exchange process that enables new relaxation pathways unavailable to the free small molecules. ${ }^{19}$ In the case of $\mathrm{CO}_{2}$, exchange was confirmed by magnetization transfer. The high lability of the $\mathrm{CO}_{2}$ ligand was reflected in the reactivity of 2 . Addition of excess acid to 2 at room temperature resulted in $\mathrm{CO}_{2}$ dissociation and formation of $\mathrm{Mo}(\mathrm{II})$ dication 5 (Scheme 1), via a Mo hydride cation, ${ }^{20}$ which has been observed in stoichiometric reactions with acid. In $\mathrm{CO}_{2}$ reduction electrocatalysis, conversion to the metal hydride moves selectivity away from $\mathrm{CO}$, affording either formate or $\mathrm{H}_{2}$, and representing a branching point in terms of defining the selectivity of $\mathrm{CO}_{2}$ reduction. ${ }^{21}$
Despite its implication as a critical step in $\mathrm{CO}_{2}$ to $\mathrm{CO}$ reduction catalysis, ${ }^{22}$ there is a paucity of reports of the protonation of well-defined $\mathrm{CO}_{2}$ adducts of transition metals. ${ }^{13 a, 23}$ Indeed, protolytic dissociation and subsequent gas analysis was a common characterization technique for metal- $\mathrm{CO}_{2}$ complexes. ${ }^{24}$

Borane LAs have been employed to activate metal coordinated small molecules. ${ }^{13,13 c, 25}$ Addition of the strong LA tris(pentafluorophenyl)borane $\left(\mathrm{B}\left(\mathrm{C}_{6} \mathrm{~F}_{5}\right)_{3}\right)$ to complex 1 affords the $\mathrm{LA} /$ base adduct 3 (Scheme 1 ), as confirmed by XRD (Figure 2). The bond metrics of complex 3 are consistent with significant activation of the $\mathrm{N}_{2}$ unit. $^{26}$ The solid-state IR spectrum corroborates weakening of the $\mathrm{N}-\mathrm{N}$ bond, with the stretch red shifting by $134 \mathrm{~cm}^{-1}$. NMR spectroscopy supports a strong borane/nitrogen interaction in solution, with both the ${ }^{19} \mathrm{~F}(-135.0,-157.9$, and $166.8 \mathrm{ppm})^{27}$ and ${ }^{11} \mathrm{~B}(-14.4 \mathrm{ppm})^{28}$ spectra consistent with four-coordinate boron.

Treating 3 with $\mathrm{CO}_{2}$, or $\mathbf{2}$ with $\mathrm{B}\left(\mathrm{C}_{6} \mathrm{~F}_{5}\right)_{3}$, results in the formation of a new LA adduct, 4 , quantitatively. Contrasting the equilibrium between complexes 1 and 2 , which slightly favors $\mathrm{N}_{2}$ binding $\left(\mathrm{K}_{\mathrm{eq}}=0.48\right)$, addition of $\mathrm{B}\left(\mathrm{C}_{6} \mathrm{~F}_{5}\right)_{3}$ renders $\mathrm{CO}_{2}$ binding irreversible (Scheme 1), likely a consequence of the strong $\mathrm{B}-\mathrm{O}$ interaction; $\mathbf{4}$ is stable under $\mathrm{N}_{2}$ in both the solid-state and solution. The triplet for the ${ }^{13} \mathrm{CO}_{2}$ unit of isotopically labeled $4{ }^{13} \mathrm{C}$ moves downfield relative to $2\left(218.9 \mathrm{ppm}, \mathrm{C}_{6} \mathrm{D}_{6}\right)$ and exhibits smaller ${ }^{2} J(\mathrm{C}, \mathrm{P})$ scalar coupling $(11.47 \mathrm{~Hz})$. Akin to 3 , the ${ }^{11} \mathrm{~B}$ and ${ }^{19} \mathrm{~F}$ NMR data are consistent with four-coordinate boron.

The solid-state structure of 4 exhibits a $\mu-\eta^{2} \mathrm{C}, \mathrm{O}: \eta \mathrm{O}$ bridging $\mathrm{CO}_{2}$ unit between Mo and B (Figure 2). Borane binding to metal-coordinated $\mathrm{CO}_{2}$ is rare, ${ }^{13 \mathrm{c}}$ but 4 displays similar bond metrics to such complexes. The structural parameters are consistent with significant $\mathrm{CO}_{2}$ activation, a phenomenon also borne out in the IR spectrum. The stretches for the $\mathrm{CO}_{2}$ unit shift to $1602 \mathrm{~cm}^{-1}$ and $1218 \mathrm{~cm}^{-1}$, as confirmed by isotopic labeling.

When stabilized with a LA, the reactivity of the $\mathrm{Mo} \mathrm{CO}_{2}$ complexes is decidedly different. The reaction of $4{ }^{13} \mathbf{C}$ with $\mathrm{HBAr}^{\mathrm{F}}{ }_{24}$ results in the formation of a single diamagnetic Mo complex (Scheme 1). The ${ }^{31} \mathrm{P}\left\{{ }^{1} \mathrm{H}\right\}$ and ${ }^{13} \mathrm{C}\left\{{ }^{1} \mathrm{H}\right\}$ NMR spectra display a doublet $(92.64 \mathrm{ppm})$ and triplet $(220.08 \mathrm{ppm})$, respectively $\left({ }^{2} J(\mathrm{P}, \mathrm{C})=14.6 \mathrm{~Hz}\right)$, consistent with $\mathrm{CO}_{2}$ cleavage to a metal-bound carbonyl. The identity of this product was confirmed as carbonyl hydride cation, $6-{ }^{13} \mathrm{C}$, via $\mathrm{XRD}$ and independent synthesis. ${ }^{29}$

A balanced reaction for the formation of 6 requires a reductant. When run under $\mathrm{N}_{2}$, the electrons are provided by 1 , which is generated under the reaction conditions upon borane displacement. Concomitantly with generation of 6, a paramagnetic $\mathrm{Mo}(\mathrm{I})-\mathrm{N}_{2}-\mathrm{Mo}(\mathrm{I})$ dinuclear complex, 
7, is formed, as confirmed by XRD. Quantifying conversion to 6 shows ca. $33 \% \mathrm{C}-\mathrm{O}$ cleavage, consistent with a process involving 1 acting as a single electron reductant; one electron oxidation of 1 with $[\mathrm{Fc}]\left[\mathrm{BAr}^{\mathrm{F}}{ }_{24}\right]$ likewise provides 7 . Borane speciation in the protonation reactions was tracked by ${ }^{19} \mathrm{~F}$ NMR spectroscopy, supporting formation of a bis(borane) hydroxide ${ }^{30}$ and subsequent protonation to a borane aquo adduct. ${ }^{31}$ Remarkably, LA coordination "turns on" $\mathrm{C}-\mathrm{O}$ cleavage chemistry, affording $\mathrm{CO}$ and $\mathrm{H}_{2} \mathrm{O}$ from $\mathrm{CO}_{2}$ and acid. Borane binding facilitates the delocalization of electron density from the low-valent Mo center into the LUMO of $\mathrm{CO}_{2}$, in a push-pull mechanism, similar to the "bifunctional attack" proposed for $\mathrm{NiFe}-\mathrm{CODH}{ }^{7}$

Figure 3. $\mathrm{CO}_{2}$ Activation as a function of Lewis Acidity. ${ }^{*}$

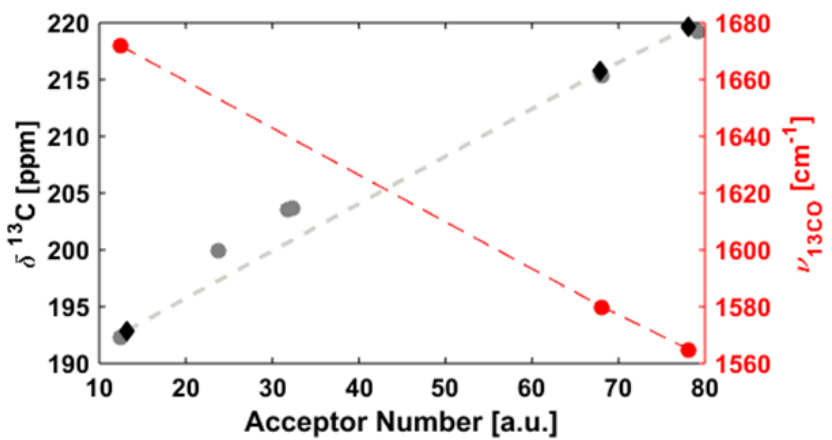

${ }^{\text {t }}$ The ${ }^{13} \mathrm{C}$ chemical shift of the $\mathrm{CO}_{2}$ ligand, in $\mathrm{PhCl}(\bullet)$ and $\mathrm{PhCl} / \mathrm{Et}_{2} \mathrm{O}(\bullet)$, tracks inversely with the $\mathrm{C}-\mathrm{O}$ stretching frequency $(\bullet)$.

Interested in the generality of the $\mathrm{CO}_{2}$ activation observed upon LA coordination to 2, a series of alkali metal $\left(\mathrm{Na}\left(\mathrm{BAr}_{24}{ }^{\mathrm{F}}\right)\right.$ and $\left.\mathrm{Cs}\left(\mathrm{BAr}^{\mathrm{F}}{ }_{24}\right)\right)$ and borane $\left(\mathrm{B}\left(\mathrm{C}_{6} \mathrm{H}_{2} \mathrm{~F}_{3}\right)_{3}, \mathrm{~B}\left(\mathrm{C}_{6} \mathrm{~F}_{5}\right)_{3}\right.$, and $\left.\mathrm{B}\left(\mathrm{C}_{6} \mathrm{H}_{3}\left(\mathrm{CF}_{3}\right)_{2}\right)_{3}\right)$ LAs were added to $2-{ }^{13} \mathrm{C}$. In each case, ${ }^{13} \mathrm{C}\left\{{ }^{1} \mathrm{H}\right\}$ and ${ }^{31} \mathrm{P}\left\{{ }^{1} \mathrm{H}\right\}$ NMR spectroscopies supported adduct formation, displaying resonances shifted downfield and upfield, respectively, from those of 2 (Tables 1 and S2). The degree of $\mathrm{CO}_{2}$ activation, as reported by the ${ }^{13} \mathrm{C}$ chemical shift, trends linearly with the strength of the LA, as quantified by the acceptor number (AN, Figure 3). ${ }^{32} \mathrm{~A}$ similar linear trend is seen when comparing $\mathrm{AN}$ vs. $v_{\mathrm{CO} 2}{ }^{33}$ suggesting that, in this case, the ${ }^{13} \mathrm{C}$ chemical shift of the bound $\mathrm{CO}_{2}$ ligand correlates with the degree of $\mathrm{C}-\mathrm{O}$ bond activation.

Revisiting protonation with these new LA adducts (Scheme 2), ${ }^{34}$ we were gratified to see that in all cases, $\mathrm{C}-\mathrm{O}$ bond cleavage was enhanced (Table 1). The extent of $\mathrm{C}-\mathrm{O}$ cleavage ${ }^{35}$ in $\mathrm{PhCl} / \mathrm{Et}_{2} \mathrm{O}^{36}$ increased to roughly the same level, in the rage of $4-9 \%$, and not proportionally with the LA AN. Changing to neat $\mathrm{PhCl}$ resulted in a further increase to bond cleavage up to $13-16 \%$. Importantly, a two-fold increase in formation of 6- ${ }^{13} \mathrm{C}$ is observed for $\mathrm{B}\left(\mathrm{C}_{6} \mathrm{H}_{2} \mathrm{~F}_{3}\right)_{3}$ and $\mathrm{B}\left(\mathrm{C}_{6} \mathrm{~F}_{5}\right)_{3}$ adducts of $2-{ }^{13} \mathrm{C}$, despite little perturbation in their respective ${ }^{13} \mathrm{C}$ NMR chemical shifts between the two solvent systems. These data are inconsistent

Scheme 2. Protonation of in situ formed LA adducts.

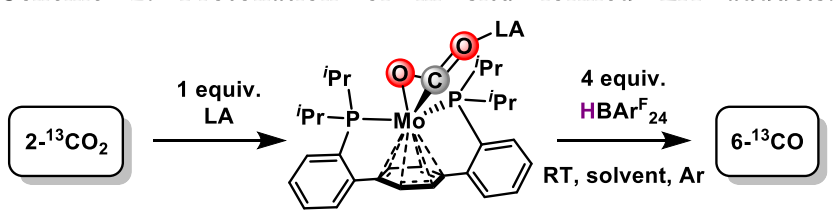

Table 1: $\mathrm{CO}_{2}$ Activation, Exchange Rate, and Cleavage Data

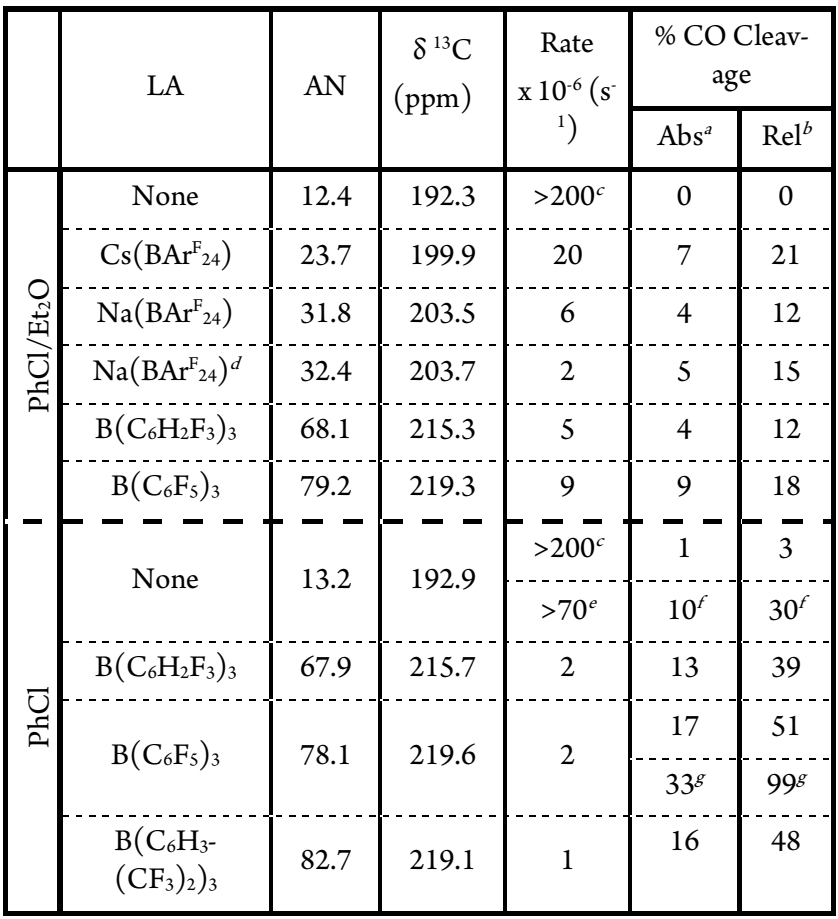

${ }^{2}$ Determined by relative integration $\left({ }^{31} \mathrm{P}\right.$ NMR spectroscopy) against a $\mathrm{Ph}_{3} \mathrm{P}=\mathrm{O}$ internal standard. ${ }^{b}$ Relative to a theoretical maximum of $33 \%$. ' Isotope equilibration was too rapid for accurate determination of the rate. ${ }^{\mathrm{T}} \mathrm{The}\left[\mathrm{Na}\left(\mathrm{BAr}^{\mathrm{F}}{ }_{24}\right)\right]$ was doubled. ${ }^{\circ}$ Measured at $-13^{\circ} \mathrm{C}$. ${ }^{\mathrm{f}} \mathrm{Acid}$ was added immediately upon thawing of the reaction solution. ${ }^{g} 1$ equiv. of $\mathrm{HBAr}_{24}^{\mathrm{F}}$ was added.

with the hypothesis that $\mathrm{C}-\mathrm{O}$ activation alone controls $\mathrm{CO}_{2}$ reduction chemistry.

We next investigated the kinetics of degenerate $\mathrm{CO}_{2}$ exchange as a measure for the impact of LA binding on the lability of the $\mathrm{Mo}-\mathrm{CO}_{2}$ interaction (Scheme 3). Exposing solutions of $2-{ }^{13} \mathrm{C}$ and a $\mathrm{LA}$ additive to an excess of ${ }^{12} \mathrm{CO}_{2}$ at $0{ }^{\circ} \mathrm{C}$, resulted in decay of the resonance associated with bound $\mathrm{CO}_{2}$ in the ${ }^{13} \mathrm{C}\left\{{ }^{1} \mathrm{H}\right\}$ NMR spectrum, providing a handle for kinetic analysis. The LA-free exchange rate is over two orders of magnitude faster than those of the LA-stabilized adducts. However, a systematic dependence of the exchange rates on the strength of the added LA was not observed (Table 1). The exchange rates are similar for most of the LAs, irrespective of their $\mathrm{AN}$ or the ${ }^{13} \mathrm{C}$ chemical shift of the adduct they form.

\section{Scheme 3. $\mathrm{CO}_{2}$ Self-Exchange in $\mathrm{Mo}-\mathrm{CO}_{2} \mathrm{LA}$ Adducts}

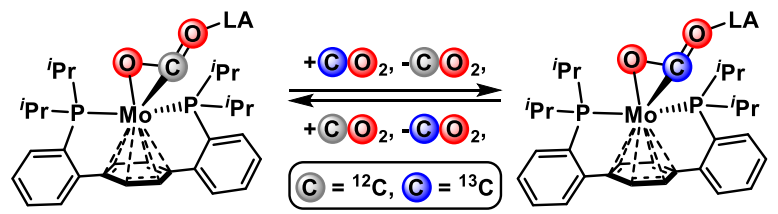

Some trends are evident from the combined kinetic data (Table 1). Borane LA adducts exchange $\mathrm{CO}_{2}$ marginally faster in the presence of $\mathrm{Et}_{2} \mathrm{O}$, a competing Lewis base, supporting LA dissociation as a rate effecting step. Likewise, increasing the concentration of LA slows self-exchange, further corroborating a mechanism involving LA dissociation. For the same concentration of LA, the exchange rates are all quite similar and significantly slower than in the absence of $L A$. The promotion of CO cleavage in LA adducts correlates with this kinetic factor-the 'residence time' of the $\mathrm{CO}_{2}$ adduct, or the propensity of the substrate to remain coordinated to the metal center-not simply to the degree of $\mathrm{CO}_{2}$ 
activation. Further highlighting the importance of kinetic stabilization, $\mathrm{C}-\mathrm{O}$ cleavage was observed in the absence of $\mathrm{LA}$ when protonation was performed at low temperature (Table 1 ). $\mathrm{CO}_{2}$ self-exchange likewise showed a significant dampening upon cooling, while the degree of $\mathrm{C}-\mathrm{O}$ activation does not change. These data suggest that increased residence time of $\mathrm{CO}_{2}$ at $\mathrm{Mo}$, a consequence of the push-pull interaction, is instrumental for bond cleavage. A competing mechanism for protonation at Mo upon $\mathrm{CO}_{2}$ dissociation erodes selectivity for $\mathrm{CO}_{2}$ activation. In terms of augmenting the $\mathrm{C}-\mathrm{O}$ cleavage preference, increasing the residence time is a decisive factor, independent of the mode of tuning it (temperature vs LA binding).

In summary, a labile $\mathrm{Mo}(0) \mathrm{CO}_{2}$ adduct interacts with a variety of LAs, increasing both the degree of activation and the kinetic stability of bound $\mathrm{CO}_{2}$. LA addition enhances proton-induced cleavage to $\mathrm{CO}$ and $\mathrm{H}_{2} \mathrm{O}$, chemistry that correlates inversely with the kinetics of $\mathrm{CO}_{2}$ exchange. This work establishes the residence time of a small molecule substrate in the coordination sphere of the metal as a critical factor in engendering desirable transformation chemistry of labile substrates. LAs additives are shown to improve $\mathrm{CO}_{2}$ cleavage by kinetic stabilization, not simply thermodynamic activation.

\section{ASSOCIATED CONTENT}

\section{Supporting Information}

Detailed experimental procedures, full characterization, crystallographic details (CIF), and spectroscopic data. This material is available free of charge via the Internet at http://pubs.acs.org.

\section{AUTHOR INFORMATION}

\section{Corresponding Author}

*E-mail: agapie@caltech.edu

\section{Notes}

The authors declare no competing financial interests.

\section{ACKNOWLEDGMENT}

We thank Larry Henling and Mike Takase for invaluable crystallographic assistance T.A. is grateful for a Dreyfus fellowship and J.A.B. for a NSF graduate research fellowship. We thank the NSF (CHE-1151918 and CHE-1800501), the Dow Next Generation Education Fund, and Caltech for funding.

\section{REFERENCES}

(1) a) Liu, Q.; Wu, L.; Jackstell, R.; Beller, M. 2015, 6, 5933; b) Aresta, M.; Dibenedetto, A.; Angelini, A. Chem. Rev. 2014, 114, 1709; c) Appel, A. M.; Bercaw, J. E.; Bocarsly, A. B.; Dobbek, H.; DuBois, D. L.; Dupuis, M.; Ferry, J. G.; Fujita, E.; Hille, R.; Kenis, P. J. A.; Kerfeld, C. A.; Morris, R. H.; Peden, C. H. F.; Portis, A. R.; Ragsdale, S. W.; Rauchfuss, T. B.; Reek, J. N. H.; Seefeldt, L. C.; Thauer, R. K.; Waldrop, G. L. Chem. Rev. 2013, 113, 6621; d) Olah, G. A.; Prakash, G. K. S.; Goeppert, A. J. Am. Chem. Soc. 2011, 133, 12881; e) Aresta, M.; Dibenedetto, A. Dalton Trans. 2007, 2975.

(2) a) Belmabkhout, Y.; Guillerm, V.; Eddaoudi, M. Chem. Eng. J. 2016, 296 386; $\quad$ b) Schoedel, A.; Ji, Z.; Yaghi, O. M. Nature Energy 2016, 1, 16034; c) Leung, D. Y. C.; Caramanna, G.; Maroto-Valer, M. M. Renew. Sust. Energ. Rev. 2014, 39, 426.

(3) a) Zhang, X.; Fevre, M.; Jones, G. O.; Waymouth, R. M. Chem. Rev. 2018, 118, 839; b) Sakakura, T.; Choi, J.-C.; Yasuda, H. Chem. Rev. 2007, 107, 2365; c) Coates, G. W.; Moore, D. R. Angew. Chem. Int. Ed. 2004, 43, 6618.

(4) a) Sordakis, K.; Tang, C.; Vogt, L. K.; Junge, H.; Dyson, P. J.; Beller, M.; Laurenczy, G. Chem. Rev. 2018, 118, 372; b) Bernskoetter, W. H.; Hazari, N. Acc. Chem. Res. 2017, 50, 1049; c) Mellmann, D.; Sponholz, P.; Junge, H.; Beller, M. Chem. Soc. Rev. 2016, 45, 3954; d) Bielinski, E. A.; Lagaditis, P. O.; Zhang, Y.; Mercado, B. Q.; Würtele, C.; Bernskoetter, W. H.; Hazari, N.; Schneider, S. J. Am. Chem. Soc. 2014, 136, 10234.
(5) a) Costentin, C.; Robert, M.; Saveant, J.-M. Chem. Soc. Rev. 2013, 42, 2423; b) Benson, E. E.; Kubiak, C. P.; Sathrum, A. J.; Smieja, J. M. Chem. Soc. Rev. 2009, 38, 89; c) Rakowski Dubois, M.; Dubois, D. L. Acc. Chem. Res. 2009, $42,1974$.

(6) a) Grice, K. A. Coord. Chem. Rev. 2017, 336, 78; b) Paparo, A.; Okuda, J. Coord. Chem. Rev. 2017, 334, 136.

(7) Fesseler, J.; Jeoung, J.-H.; Dobbek, H. Angew. Chem. Int. Ed. 2015, 54, 8560.

(8) Qiao, J.; Liu, Y.; Hong, F.; Zhang, J. Chem. Soc. Rev. 2014, 43, 631.

(9) a) Forrest, S. J. K.; Clifton, J.; Fey, N.; Pringle, P. G.; Sparkes, H. A.; Wass, D. F. Angew. Chem. Int. Ed. 2015, 54, 2223; b) Jeoung, J.-H.; Dobbek, H. Science 2007, 318, 1461

(10) a) Sampson, M. D.; Kubiak, C. P. J. Am. Chem. Soc. 2016, 138, 1386; b) Bhugun, I.; Lexa, D.; Savéant, J.-M. J. Phys. Chem. 1996, 100, 19981; c) Hammouche, M.; Lexa, D.; Momenteau, M.; Saveant, J. M. J. Am. Chem. Soc. 1991, 113, 8455.

(11) a) Takaya, J.; Iwasawa, N. J. Am. Chem. Soc. 2017, 139, 6074; b) Cammarota, R. C.; Vollmer, M. V.; Xie, J.; Ye, J.; Linehan, J. C.; Burgess, S. A.; Appel, A. M.; Gagliardi, L.; Lu, C. C. J. Am. Chem. Soc. 2017, 139, 14244; c) Devillard, M.; Declercq, R.; Nicolas, E.; Ehlers, A. W.; Backs, J.; Saffon-Merceron, N.; Bouhadir, G.; Slootweg, J. C.; Uhl, W.; Bourissou, D. J. Am. Chem. Soc. 2016, $138,4917$.

(12) a) Bagherzadeh, S.; Mankad, N. P. J. Am. Chem. Soc. 2015, 137, 10898; b) Krogman, J. P.; Foxman, B. M.; Thomas, C. M. J. Am. Chem. Soc. 2011, 133, 14582 .

(13) a) Yoo, C.; Lee, Y. Chem. Sci. 2017, 8, 600; b) Rauch, M.; Parkin, G.J. Am. Chem. Soc. 2017, 139, 18162; c) Kim, Y.-E.; Kim, J.; Lee, Y. Chem. Commun. 2014, 50, 11458; d) Jiang, Y.; Blacque, O.; Fox, T.; Berke, H. J. Am. Chem. Soc. 2013, 135, 7751.

(14) a) Jin, G.; Werncke, C. G.; Escudié, Y.; Sabo-Etienne, S.; Bontemps, S.J. Am. Chem. Soc. 2015, 137, 9563; b) Chakraborty, S.; Zhang, J.; Krause, J. A.; Guan, H. J. Am. Chem. Soc. 2010, 132, 8872; c) Laitar, D. S.; Müller, P.; Sadighi, J. P. J. Am. Chem. Soc. 2005, 127, 17196.

(15) Mo complexes have been employed previously for $\mathrm{CO}_{2}$ reduction chemistry. For select examples, see: a) Zhang, Y.; Williard, P. G.; Bernskoetter, W. H. Organometallics 2016, 35, 860; b) Neary, M. C.; Parkin, G. Chem. Sci. 2015, 6, 1859; c) Clark, M. L.; Grice, K. A.; Moore, C. E.; Rheingold, A. L.; Kubiak, C. P. Chem. Sci. 2014, 5, 1894.

(16) a) Carden, R. G.; Ohane, J. J.; Pike, R. D.; Graham, P. M. Organometallics 2013, 32, 2505; b) Bernskoetter, W. H.; Tyler, B. T. Organometallics 2011, 30, 520; c) Contreras, L.; Paneque, M.; Sellin, M.; Carmona, E.; Perez, P.J.; Gutierrez-Puebla, E.; Monge, A.; Ruiz, C. NewJ. Chem. 2005, 29, 109; d) Alvarez, R.; Carmona, E.; Marin, J. M.; Poveda, M. L.; Gutierrez-Puebla, E.; Monge, A. J. Am. Chem. Soc. 1986, 108, 2286.

(17) Gambarotta, S.; Floriani, C.; Chiesi-Villa, A.; Guastini, C. J. Am. Chem. Soc. 1985, 107, 2985.

(18) a) Seravalli, J.; Ragsdale, S. W. Biochemistry2008, 47, 6770; b) We could not find a reported $\mathrm{T}_{1}$ time for $\mathrm{N}_{2}$ gas in organic solvent. There are, however, extensive studies on ${ }^{15} \mathrm{~N}$ relaxation parameters at low temperature in liquid $\mathrm{N}_{2}$. See Ishol, L.M.; Scott, T.A.; Goldblatt, M. J. Mag. Res. 1976, 23, 313.

(19) Ishol, L. M.; Scott, T. A.; Goldblatt, M. J. Mag. Res. 1976, 23, 313.

(20) Buss, J. A.; Edouard, G. A.; Cheng, C.; Shi, J.; Agapie, T. J. Am. Chem. Soc. 2014, 136, 11272 .

(21) Schneider, J.; Jia, H.; Muckerman, J. T.; Fujita, E. Chem. Soc. Rev. 2012, 41, 2036.

(22) a) Chapovetsky, A.; Do, T. H.; Haiges, R.; Takase, M. K.; Marinescu, S. C. J. Am. Chem. Soc. 2016, 138, 5765; b) Sampson, M. D.; Nguyen, A. D.; Grice, K. A.; Moore, C. E.; Rheingold, A. L.; Kubiak, C. P. J. Am. Chem. Soc. 2014, 136, 5460; c) Bhugun, I.; Lexa, D.; Savéant, J.-M. J. Am. Chem. Soc. 1996, 118, 1769; d) DuBois, D. L.; Miedaner, A.; Haltiwanger, R. C. J. Am. Chem. Soc. 1991, 113, 8753; e) Ishida, H.; Tanaka, K.; Tanaka, T. Organometallics 1987, 6, 181.

(23) a) Sahoo, D.; Yoo, C.; Lee, Y. J. Am. Chem. Soc. 2018, 140, 2179; b) Tsai, J. C.; Khan, M.; Nicholas, K. M. Organometallics 1989, 8, 2967.

(24) Vol'pin, M. E. K., I.S. Pure Appl. Chem. 1973, 33, 567.

(25) a) Geri, J. B.; Shanahan, J. P.; Szymczak, N. K. J. Am. Chem. Soc. 2017, 139, 5952; b) Simonneau, A.; Turrel, R.; Vendier, L.; Etienne, M. Angew. Chem. Int. Ed.2017, 56, 12268.

(26) The N1-N2 distance elongates by $0.06 \AA$ and the N2-B distance, at $1.586(5) \AA$, is similar to that of a reported borane $\mathrm{N}_{2}$ adduct (see ref $25 \mathrm{a}$ ).

(27) a) Parks, D. J.; Piers, W. E.; Yap, G. P. A. Organometallics 1998, 17, 5492; b) Horton, A. D.; de With, J. Organometallics 1997, 16, 5424. 
(28) Lewiński, J.; Kubicki, D. In Encyclopedia of Spectroscopy and Spectrometry (Third Edition); Tranter, G. E., Koppenaal, D. W., Eds.; Academic Press: Oxford, 2017, p 318.

(29) Cation 6 is accessible via addition of $\operatorname{HBAr}^{\mathrm{F}} 24$ to a $\mathrm{Mo}(0)$ monocarbonyl complex (Scheme S1).

(30) Xu, T.; Chen, E. Y. X. J. Am. Chem. Soc. 2014, 136, 1774.

(31) Bergquist, C.; Bridgewater, B. M.; Harlan, C. J.; Norton, J. R.; Friesner, R. A.; Parkin, G. J. Am. Chem. Soc. 2000, 122, 10581.

(32) Beckett, M. A.; Strickland, G. C.; Holland, J. R.; Sukumar Varma, K. Polymer 1996, 37, 4629.
(33) Even with isotopic enrichment, the $\mathrm{C}-\mathrm{O}$ stretches of the alkali metal LA adducts were inadequately resolved to be assigned with confidence. This limits the available IR data to three points; however, a clear linear trend is observed for both the ${ }^{12} \mathrm{C}$ and ${ }^{13} \mathrm{C}$ isotoplogues.

(34) These reactions were performed with strict exclusion of $\mathrm{N}_{2}$ to avoid potential exchange prior to protonation.

(35) The theoretical maximum of which is $33 \%$ (vide supra).

(36) Protonation experiments were performed in a $2 \mathrm{PhCl}: 1 \mathrm{Et}_{2} \mathrm{O}$ solvent mixture, which solubilizes both alkali metal and borane LAs and their adducts. 
For Table of Contents Only

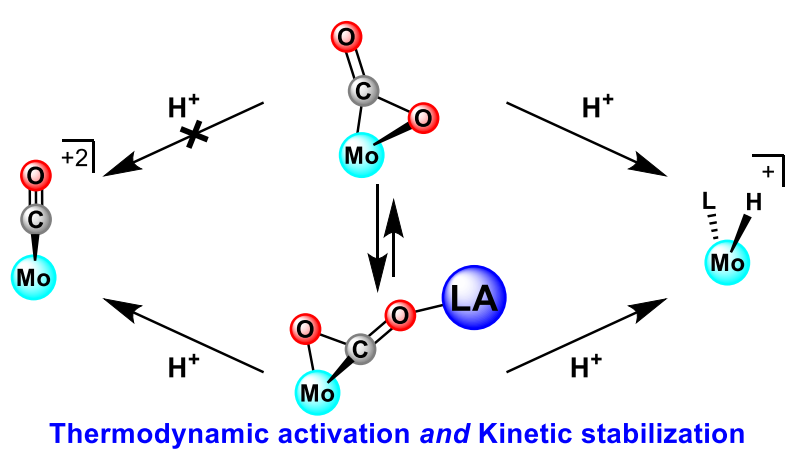

